ISSN 1412-2936

EISSN 2549-7308

\title{
PENGARUH ATRIBUT PRODUK DAN HARGA TERHADAP PROSES KEPUTUSAN PEMBELIAN SERTA DAMPAKNYA TERHADAP TINGKAT KEPUASAN PELANGGAN PRODUK KELOM SHENY DI KOTA TASIKMALAYA
}

\author{
Depy Muhamad Pauzy \\ depypauzy89@gmail.com
}

Arga Sutrisna

Universitas Perjuangan Tasikmalaya

\begin{abstract}
This study aims to determine how the influence of product attributes and prices on purchasing decisions and their impact on the level of customer satisfaction on Kelom Sheny products in Tasikmalaya. This research is descriptive and empirical. Descriptive research was conducted to obtain an overview of product attributes, prices, purchasing decisions, and customer satisfaction. While empirical research was conducted to determine the relationship between variables through statistical calculations. Data collection techniques through questionnaires to 100 respondents randomly. The objects in this study are all consumers around Tasikmalaya. Research data will be analyzed using path analysis where product and price attributes are independent variables, the purchasing decision process as an intervening variable and customer satisfaction as the dependent variable.
\end{abstract}

Keywords: Kelom Sheny; product attributes, prices, purchasing decisions, customer satisfaction.

\section{ABSTRAK}

Penelitian ini bertujuan untuk mengetahui bagaimana pengaruh atribut produk dan harga terhadap keputusan pembelian serta dampaknya terhadap tingkat kepuasan pelanggan pada produk Kelom Sheny di Kota Tasikmalaya. Penelitian ini bersifat deskriptif dan empiris. Penelitian deskriptif dilakukan untuk memperoleh gambaran tentang atribut produk, harga, keputusan pembelian, dan kepuasan pelanggan. Sedangkan penelitian empiris dilakukan untuk mengetahui hubungan antara variabel melalui perhitungan-perhitungan statistik. Teknik pengumpulan data melalui penyebaran angket kepada 100 orang responden secara random (acak). Objek dalam penelitian ini adalah semua konsumen yang berada di sekitar wilayah Kota Tasikmalaya. Data penelitian akan dianalisis menggunakan path analysis dimana atribut produk dan harga menjadi variabel bebas, proses keputusan pembelian sebagai variabel intervening/perantara dan kepuasan pelanggan sebagai variabel terikat..

Kata kunci: Kelom Sheny; atribut produk, harga, keputusan pembelian, kepuasan pelanggan.

\section{PENDAHULUAN}

Manusia adalah makhluk yang tidak pernah puas dan cenderung memiliki keinginan yang tidak terbatas. Bagi para produsen, kalimat tersebut merupakan sebuah celah peluang yang harus dimanfaatkan untuk berbisnis, sehingga dapat menghasilkan suatu keuntungan atau laba.

Secara teoritis terdapat banyak cara atau alternatif yang bisa ditempuh oleh suatu perusahaan dalam rangka mencapai dan meningkatkan volume keputusan yang diambil konsumen dalam membeli produk-produk atau jasa- 
jasa yang ditawarkan oleh produsen. Berkaitan dengan hal tersebut, dalam fungsi pemasaran, upaya untuk mencapai penjualan yang menguntungkan tidak lepas dari kemampuan perusahaan dalam menguasai pemasaran.

Pemasaran biasanya dihadapkan pada masalah produk, harga, distribusi dan promosi, disamping masalah tersebut biasanya masalah yang lain yaitu tentang keputusan pembelian konsumen. Kegiatan pemasaran bertujuan untuk mempengaruhi konsumen dalam pembelian suatu produk dan didalam melakukan pembelian, konsumen membutuhkan informasi tentang produk yang akan dibeli, salah satunya adalah informasi tentang merek produk. Persepsi konsumen terhadap suatu produk akan menjadi pertimbangan konsumen dalam menentukan pilihan produk mana yang akan dibeli. Produk yang dibeli oleh konsumen tergantung dari pengalaman dan kebiasaan konsumen terhadap suatu merek. Merek sendiri sebagai identitas dari produk atau perusahaan. Merek tidak hanya sekedar nama, melainkan cerminan perusahaan.

Pada dunia pemasaran, persaingan merupakan hal yang lumrah dan wajar, maka dari itu berbagai usaha dilakukan dalam upaya memenangkan persaingan. Salah satu diantaranya adalah membuat desain produk yang menarik sehingga dapat mengundang konsumen untuk membeli produk yang dipasarkan.

Ibu-ibu rumah tangga biasanya sangat apik dalam membeli dan menyeleksi, misalnya dalam kualitas produk, merek, desain produk, dan harga produk, mereka lebih menginginkan dengan harga yang relatif terjangkau mendapatkan produk yang berkualitas apalagi produk yang sudah mempunyai merek. Proses pengambilan keputusan sangat bervariasi, ada yang sederhana dan ada yang sangat kompleks. Pengambilan keputusan tidak hanya berakhir dengan terjadinya transaksi pembelian akan tetapi diikuti pula sampai tahap perilaku pembeli.
Konsep pemasaran menegaskan bahwa kunci untuk mencapai sasaran organisasi adalah perusahaan harus menjadi lebih efektif dibandingkan para pesaing dalam menciptakan, menyerahkan, dan mengkonsumsi nilai pelanggan kepada pasar sasaran yang terpilih (1). Bagi perusahaan, pemasaran lebih mengarah kepada pemenuhan kebutuhan dan kepuasan konsumen dalam jangka panjang. Mengingat keinginan konsumen yang beragam, penting bagi pihak perusahaan untuk mengetahui dan memahami perilaku pembelian konsumen, sehingga perusahaan mampu mengembangkan barang dan jasa sesuai dengan kebutuhan konsumen.

Lingkungan persaingan produk yang semakin ketat dengan masuknya produk-produk inovatif kepasaran yang mana terdapat kondisi pasar yang jenuh untuk produk-produk, di sisi lain usaha untuk mengelola loyalitas konsumen menjadi tantangan yang tidak mudah, konsumen memiliki beraneka ragam kebutuhan dan keinginan yang dapat dipenuhi dengan mengonsumsi produk tertentu, tetapi keterbatasan daya beli dan kesediaan untuk membeli membuat tidak semua kebutuhan dan keinginan bisa direalisasikan. Meningkatnya pembelian konsumen akan mampu meningkatkan daya saing perusahaan tersebut terhadap perusahaan pesaing. Jika organisasi ingin mencapai tujuannya maka salah satu caranya adalah pemasar membedakan produknya dengan pesaing dengan menyediakan atribut produk yang unik. Oleh karena itu, penting bagi pemasar untuk mengetahui sejauh manakah atribut produknya mampu menarik konsumen untuk membelinya.

Kepuasan pelanggan atau konsumen merupakan salah satu tahap yang harus dicapai untuk dapat mendapatkan kepercayaan dari konsumen di tengah maraknya persaingan usaha. Lim et.al. (2), menyatakan kepercayaan konsumen dalam berbelanja sebagai kesediaan konsumen untuk mengekspos dirinya terhadap kemungkinan rugi yang dialami 
selama transaksi berbelanja, didasarkan harapan bahwa penjual menjanjikan transaksi yang akan memuaskan konsumen.

Salah satu produk andalan Kota Tasikmalaya yaitu Kelom Geulis Tasikmalaya. Kelom Geulis Tasikmalaya di ambil dari bahasa belanda 'kelompen' yang artinya sandal kayu. Istilah Kelom Geulis Tasikmalaya sendiri berasal dari bahasa sunda yang berarti sandal kayu cantik. Sandal kelom biasanya di pakai untuk acara hajatan ataupun acara resmi. Kelom Geulis Tasikmalaya terbuat dari kayu mahoni atau albasia. Kelom Geulis Tasikmalaya ini di buat secara manual dengan menggunakan tangan. Agar tampak menarik, kelom di berikan hiasan. Hiasan kelom umumnya adalah hiasan ukiran dengan motif bunga. Sekarang ini, terdapat juga kelom dengan menggunakan hiasan cat air brush dan juga hiasan batik atau yang lebih di kenal dengan kelom batik. Kerajinan Kelom Geulis Tasikmalaya banyak di produksi sebagai Home Industry sebagai contoh Kelom Sheny yang bertempat di Gunung Kanyere Tamansari Kota Tasikmalaya, tetapi atas kenyataan lapangan bahwa dalam kurun waktu satu tahun terakhir telah terjadi penurunan penjualan produk Kelom Sheny. Diduga penyebab penurunan tersebut dipengaruhi berbagai faktor, diantaranya adalah penyediaan produk yang kurang lengkap serta potongan harga yang jarang dilakukan, serta daya beli konsumen semakin menurun.

Berdasarkan uraian diatas maka penulis cenderung mengambil judul "Pengaruh Atribut Produk dan Harga Terhadap Proses Keputusan Pembelian Serta Dampaknya Terhadap Tingkat Kepuasan Pelanggan Produk Kelom Sheny Di Kota Tasikmalaya"

Berdasarkan latar belakang tersbut diatas, dan berkaitan dengan permasalahan mengenai kepuasan pelanggan produk kelom Sheny di Kota Tasikmalaya maka pokok permasalahannya sebagai berikut :

1. Bagaimana merek, desain produk, harga, keputusan pembelian, dan kepuasan pelanggan.
2. Bagaimana pengaruh merek, desain produk dan harga secara parsial maupun simultan terhadap keputusan pembelian.

3. Bagaimana pengaruh keputusan pembelian terhadap kepuasan pelanggan

Tujuan penelitian yang ingin dicapai adalah sebagai berikut :

1. Untuk mengetahui bagaimana merek, desain produk, harga, keputusan pembelian, dan kepuasan pelanggan.

2. Untuk mengetahui bagaimana pengaruh merek, desain produk dan harga secara parsial maupun simultan terhadap keputusan pembelian.

3. Untuk mengetahui bagaimana pengaruh keputusan pembelian terhadap kepuasan pelanggan.

Adapun manfaat dari penelitian ini adalah dari sisi pengembangan ipteks dan perguruan tinggi. Penelitian ini seiring dengan visi Perguruan Tinggi (Universitas Perjuangan) yaitu hasil penelitian dapat dimanfaatkan untuk menunjang kondisi pegawai di lingkungan Universitas Perjuangan. Pengembangan ipteks di perguruan tinggi yang dipublikasikan pada jurnal ilmiah dan di seminarkan akan menambah kontribusi perguruan tinggi dalam pengembangan ipteks secara sosial. Selanjutnya, dari sisi pengembangan materi pembelajaran. Hasil penelitian dapat digunakan sebagai materi pembelajaran berbasis hasil riset (research-based learning), terutama untuk mengembangkan materi pembelajaran yang terkait dengan manajemen pemasaran.

\section{Tinjauan Pustaka}

\section{Produk}

Menurut Kotler dan Amstrong (3), menyatakan bahwa "Produk adalah segala sesuatu yang dapat ditawarkan ke pasar untuk diperhatikan, dimiliki, digunakan atau dikonsumsi yang dapat memuaskan keinginan dan kebutuhan, produk mencakup obyek fisik, jasa, orang, tempat, organisasi dan gagasan“. 
Pengertian produk menurut Gobe, Kotler, dan Amstrong (4), adalah "segala sesuatu yang dapat ditawarkan ke pasar untuk mendapat perhatian, dibeli, digunakan atau dikonsumsi yang dapat memuaskan keinginan atau kebutuhan". Klasifikasi produk menurut Fandy Tjiptono (5), dibagi kedalam dua kelompok: 1. Barang yang terdiri dari barang yang terpakai habis dan barang tahan lama. 2. Jasa merupakan aktivitas, manfaat atas kepuasan yang ditawarkan untuk dijual. Contoh: reparasi, salon kecantikan, hotel dan lain-lain.

\section{Atribut Produk}

Atribut produk dapat memberikan gambaran yang jelas tentang produk itu sendiri. Agar dapat memberikan gambaran yang jelas mengenai pengertian atribut produk, maka di bawah ini beberapa pengertian mengenai atribut produk menurut para ahli. Menurut Fandy Tjiptono (6), atribut produk merupakan unsur-unsur produk yang dipandang penting oleh konsumen dan dijadikan dasar pengambilan keputusan pembelian. Kemudian menurut Lovelock dan Wright dalam Rachim dan Setiawan (7), atribut produk adalah "semua fitur (baik yang berwujud maupun tidak berwujud) suatu barang atau jasa yang dapat dinilai pelanggan". Berdasarkan definisi di atas maka dapat disimpulkan bahwa atribut produk adalah unsur-unsur dari sebuah produk yang dipandang penting oleh konsumen dan mencerminkan pengembangan suatu produk untuk dapat dijadikan dasar dalam pengambilan keputusan pembelian. Atribut produk secara umum meliputi: 1. Desain produk, 2. Warna produk, 3. Merek, 4. Kemasan, 5. Pemberian Label, 6. Kualitas produk, 7. Layanan Pelengkap (supplementary services), 8. Jaminan.

\section{Harga}

Harga menurut Basu Swastha dalam Evelina dkk. (8), adalah "jumlah uang (ditambah beberapa barang kalau mungkin) yang dibutuhkan untuk mendapatkan sejumlah kombinasi dari barang beserta pelayanannya". Harga sering digunakan oleh konsumen sebagai indikator penentuan produk. Konsumen akan memilih barang yang harganya lebih murah, meski selisih sedikit untuk barang yang menurut mereka memiliki kualitas yang sama. Konsumen kadang juga memilih barang yang lebih mahal untuk jenis barang yang sama dengan mengharapkan kualitas yang lebih. Harga merupakan salah satu penentu keberhasilan suatu perusahaan karena harga menentukan seberapa besar keuntungan yang akan diperoleh perusahaan dari penjualan produknya baik berupa barang maupun jasa. Harga yang terlalu tinggi akan menyebabkan penjualan menurun, namun jika harga terlalu rendah akan mengurangi keuntungan yang dapat diperoleh organisasi perusahaan. Pada umumnya perusahaan menentukan harga dengan mempertimbangkan biaya yang dikeluarkan dan keuntungan yang diharapkan. Buchari Alma (9) menyatakan bahwa: "harga ditetapkan untuk mendapatkan laba maksimum, mendapatkan pengembalian investasi yang ditergetkan atau pengembalian pada penjualan bersih, mencegah atau mengurangi persaingan dan mempertahankan atau memperbaiki market share".

\section{Keputusan Pembelian}

Keputusan pembelian yang dilakukan oleh konsumen memegang peranan yang sangat penting, sebab konsumen yang telah merasa puas cenderung untuk tidak menggunakan kembali atau mengkonsumsi kembali produk yang telah memuaskannya. Selain itu konsumen yang merasa puas akan dapat memberikan informasi mengenai apa yang telah dirasakannya kepada pihak lain yang mungkin merasa tertarik untuk mengkonsumsinya. Keputusan pembelian adalah sebagai suatu tindakan-tindakan individu yang secara langsung terlibat dalam usaha memperoleh dan menggunakan barangbarang atau jasa ekonomi termasuk keputusan untuk membeli merek yang 
paling disukai konsumen, yang menyaratkan aktivitas individu tersebut untuk mengevaluasi, memperoleh dan menggunakan atau mengatur barang dan jasa tersebut berdasarkan pertimbangan antara merek-merek pilihan.(1) Keputusan untuk melakukan pembelian didorong oleh adanya kebutuhan dan keinginan terhadap produk. Proses untuk membuat keputusan untuk membeli sesuatu pada dasarnya sama seperti ketika seseorang individu sedang berusaha untuk memecahkan masalah. Menurut John Mowen (10) terdapat lima peran dalam mengambil keputusan pembelian yaitu:

1) Pencetus

Seseorang yang pertama kali mengusulkan gagasan untuk mengambil produk atau jasa.

2) Pemberi pengaruh

Seseorang dengan pandangan atau saran yang mempengaruhi keputusan.

3) Pengambil keputusan

Setiap orang yang memutuskan setiap komponen dari suatu keputusan pembelian: apakah membeli, tidak membeli, bagaimana membeli dan dimana akan membeli.

4) Pembeli

Orang yang melakukan pembelian sesungguhnya.

$$
\left[n>p q\left(\frac{\mathrm{Z}_{\alpha / 2}}{e}\right)^{2}\right]
$$

Dimana:

$n \quad=$ ukuran sampel

$Z_{\alpha / 2}=$ nilai $Z$ tabel

$e \quad=$ persentase kelonggaran ketidaktelitian karena pengambilan sampel yang masih dapat ditolerir (10\%)

$p q=$ nilai probabilitas $(p=0,5$ dan $q=0,5)$

Dengan menggunakan rumus di atas maka dapat dihitung jumlah sampel sebagai berikut

$$
\begin{aligned}
& n>0,5.0,5\left(\frac{1,96}{0,1}\right)^{2} \\
& n>96,04
\end{aligned}
$$

Berdasarkan perhitungan, maka sampel minimum yang harus diambil sebesar 96,04 responden. Dalam penelitian ini penentuan ukuran sampel yaitu untuk
Seseorang yang mengkonsumsi atau menggunakan produk atau jasa yang bersangkutan.

\section{Kepuasan Pelanggan}

Kepuasan pelanggan atau konsumen merupakan salah satu tahap yang harus dicapai untuk dapat mendapatkan kepercayaan dari konsumen di tengah maraknya persaingan usaha (2), menyatakan kepercayaan konsumen dalam berbelanja sebagai kesediaan konsumen untuk mengekspos dirinya terhadap kemungkinan rugi yang dialami selama transaksi berbelanja, didasarkan harapan bahwa penjual menjanjikan transaksi yang akan memuaskan konsumen.

\section{METODE PENELITIAN}

Objek penelitian adalah warga Tasikmalaya yang mengetahui produk kelom Sheny. Penelitian ini melakukan pengambilan sampel dengan menggunakan random sampling dimana penarikan sampel secara acak atau bebas terhadap konsumen kelom Sheny yang berada di Tasikmalaya. Penentuan ukuran sampel yang diambil menggunakan rumus yang dikemukakan oleh Slovin yang dikutip oleh Husain Umar (11) sebagai berikut
5) Pemakai 
menggunakan metode penelitian survey. Penelitian survey merupakan metode pengumpulan data primer yang diperoleh secara langsung dari sumber asli (12).

Teknik-teknik pengumpulan data yang digunakan dalam penelitian ini terdiri dari:

1. Penelitian Lapangan (Field Research) Yaitu penelitian yang dilakukan secara langsung pada objek penelitian, sehingga dapat diketahui kondisi perusahaan dengan cara sebagai berikut:

a. Wawancara

Wawancara yaitu kegitan pengumpulan data dan fakta dengan cara mengadakan tanya jawab langsung dengan pihak-pihak terkait yaitu konsumen mengenai atribut toko, kepuasan dan kepercayaan konsumen.

b. Dokumentasi

Dokumentasi yaitu pengumpulan dokumen-dokumen dan catatan perusahaan yang berhubungan dengan atribut toko, kepuasan dan kepercayaan konsumen.

c. Kuesioner

Kuesioner yaitu menyebarkan pertanyaan-pertanyaan mengenai masalah-masalah terkait kepada responden terpilih untuk mengetahui respon mereka terhadap atribut toko, kepuasan dan kepercayaan konsumen.

2. Penelitian Kepustakaan (Library Research), penelitian kepustakaan yaitu suatu metode pengumpulan data yang dilakukan dengan mempelajari literatur yang berhubungan dengan atribut produk, teori harga, proses keputusan pembelian, dan kepuasan pelanggan sehingga dapat dipakai sebagai dasar analisis. Teknik Analisis Data

Data yang diperoleh dari penelitian ini, kemudian dianalisis dengan menggunakan statistik yaitu path analisis untuk mengetahui pengaruh merek, desain produk, dan harga terhadap proses keputusan pembelian serta dampaknya terhadap kepuasan pelanggan. Berikut adalah tabel operasional variabel dimana variabel $\mathrm{X} 1$ adalah Merek, variabel X2 adalah Desain produk dan variabel $\mathrm{X} 3$ adalah harga, variabel $Y$ adalah Keputusan Pembelian, variabel $Z$ adalah kepuasan pelanggan.

\begin{tabular}{|c|c|c|c|}
\hline Variabel & Dimensi/Definisi & Indikator & Skala \\
\hline (1) & (2) & (3) & (4) \\
\hline $\begin{array}{l}\text { Atribut } \\
\text { Produk }\end{array}$ & \begin{tabular}{lr} 
atribut produk & \multicolumn{2}{c}{ merupakan } \\
unsur-unsur produk yang \\
dipandang penting & oleh \\
konsumen dan dijadikan dasar & \\
pengambilan & keputusan \\
pembelian.(6) &
\end{tabular} & $\begin{aligned} \text { - Keandalan } \\
\text { - Kemampuan } \\
\text { Pelayanan } \\
\text { - Estetika } \\
\text { - Kualitas } \\
\text { - Bentuk } \\
\text { - Model } \\
\text { - Warna }\end{aligned}$ & Ordinal \\
\hline Harga & $\begin{array}{l}\text { Harga adalah jumlah uang } \\
\text { (ditambah beberapa barang } \\
\text { kalau mungkin) yang } \\
\text { dibutuhkan untuk mendapatkan }\end{array}$ & $\begin{array}{l}\text { - Keterjangkauan } \\
\text { harga } \\
\text { - Kesesuaian harga } \\
\text { dengan kualitas }\end{array}$ & Ordinal \\
\hline
\end{tabular}


ISSN 1412-2936

EISSN 2549-7308

\begin{tabular}{|c|c|c|c|}
\hline & $\begin{array}{l}\text { sejumlah kombinasi dari barang } \\
\text { beserta pelayanannya. (8) }\end{array}$ & $\begin{array}{l}\text { produk } \\
\text { - Daya saing harga } \\
\text { - Kesesuaian harga } \\
\text { dengan manfaat }\end{array}$ & \\
\hline $\begin{array}{l}\text { Proses } \\
\text { Keputusan } \\
\text { Pembelian }\end{array}$ & $\begin{array}{l}\text { Keputusan pembelian pada } \\
\text { dasarnya untuk membeli merk } \\
\text { yang paling disukai konsumen } \\
\text { berdasarkan } \quad \text { pertimbangan } \\
\text { diantara } \\
\text { pilihan.(1) }\end{array}$ & $\begin{array}{l}\text { - Kebutuhan } \\
\text { - Media iklan } \\
\text { - Pengalaman } \\
\text { - Rangsangan } \\
\text { - Manfaat }\end{array}$ & Ordinal \\
\hline $\begin{array}{l}\text { Kepuasan } \\
\text { Pelanggan }\end{array}$ & $\begin{array}{l}\text { Kepuasan pelanggan atau } \\
\text { konsumen merupakan salah } \\
\text { satu tahap yang harus dicapai } \\
\text { untuk dapat mendapatkan } \\
\text { kepercayaan dari konsumen di } \\
\text { tengah maraknya persaingan } \\
\text { usaha. (2) }\end{array}$ & $\begin{array}{l}\text { - Kesesuain } \\
\text { harapan } \\
\text { - Minat berkunjung } \\
\text { kembali } \\
\text { - Kesediaan } \\
\text { merekomendasika } \\
\mathrm{n}\end{array}$ & Ordinal \\
\hline
\end{tabular}

Paradigma Penelitian

Untuk mengetahui gambaran umum, maka disajikan kerangka pemikiran penelitian sebagai berikut :

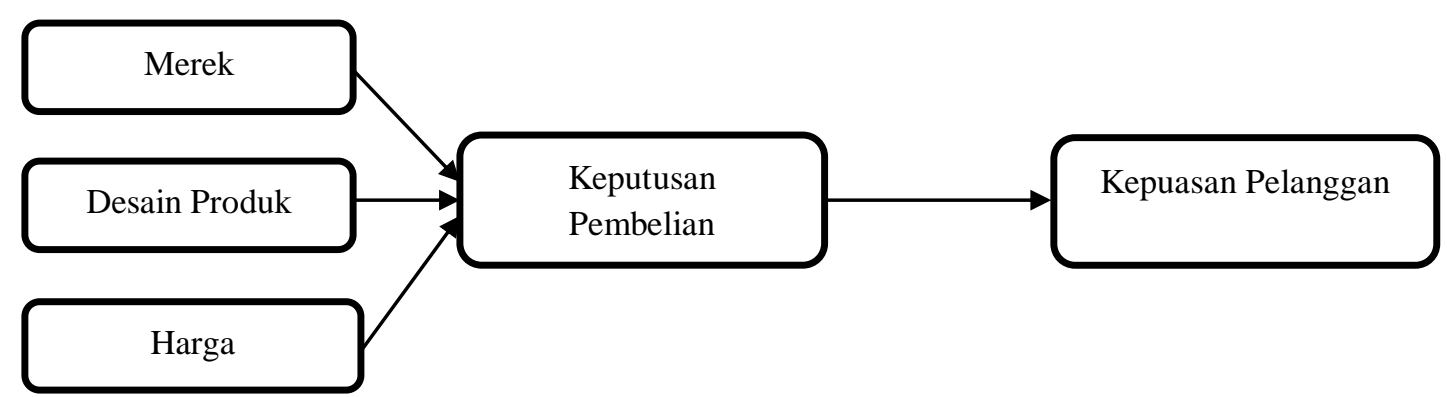

\section{PEMBAHASAN}

Dari tabel hasil uji validitas tersebut, diketahui bahwa item-item pernyataan telah valid. Hal ini menandakan bahwa seluruh item memenuhi persyaratan uji validitas intrumen. Berikut ini adalah hasil rekapitulasi hasil uji validitas yang telah diolah.

Tabel Rekapitulasi Hasil Uji Validitas Yang Telah Diolah

\begin{tabular}{l|c|c|c|c|c|c}
\hline \multirow{2}{*}{ Variabel } & \multicolumn{2}{|c|}{ Valid } & \multicolumn{2}{c|}{ Tidak Valid } & \multicolumn{2}{c}{ Total } \\
\cline { 2 - 6 } & Jumlah & $\%$ & Jumlah & $\%$ & Jumlah & $\%$ \\
\hline \hline
\end{tabular}


ISSN 1412-2936

EISSN 2549-7308

\begin{tabular}{l|c|c|c|c|c|c}
\hline Merek & 7 & 100 & - & - & 7 & 100 \\
\hline Desain Produk & 3 & 100 & - & - & 3 & 100 \\
\hline Harga & 4 & 100 & - & - & 4 & 100 \\
\hline Keputusan Pembelian & 3 & 100 & - & - & 3 & 100 \\
\hline Kepuasan Pelanggan & 3 & 100 & - & - & 3 & 100 \\
\hline
\end{tabular}

Sumber :Hasil Uji Validitas (Diolah)

Hasil akhir uji reliabilitas instrumen untuk variabel merek, desain produk, harga, keputusan pembelian dan kepuasan pelanggan dengan menggunakan metode alpha cronbach adalah sebagai berikut

Tabel Hasil Uji Reliabilitas

\begin{tabular}{c|l|c|c}
\hline No & \multicolumn{1}{|c|}{ Variabel } & Skor & Kategori \\
\hline 1 & Merek (X1) & 0,769 & Reliabel \\
\hline 2 & Desain Produk (X2) & 0,782 & Reliabel \\
\hline 3 & Harga (X3) & 0,745 & Reliabel \\
\hline 4 & Keputusan Pembelian (Y) & 0,749 & Reliabel \\
\hline 5 & Kepuasan Pelanggan (Z) & 0,715 & Reliabel \\
\hline
\end{tabular}

Sumber : Diolah dari Data Primer

Dari tabel disebut dapat diketahui bahwa seluruh istrumen yang digunakan, yaitu meliputi instrumen untuk variabel merek (X1), desain produk (X2), harga (X3), keputusan pembelian $(Y)$, dan kepuasan pelanggan (Z) semuanya menunjukkan bahwa instrumen tersebut reliabel, yaitu koefisien Alpha Cronbach lebih dari 0,60. Setelah uji validitas dan reliabilitas intrumen yang dilakukan, langkah berikutnya adalah mentransformasikan data yang ada (masih berskala ordinal) ke data berskala interval. Hal ini memenuhi persyaratan dalam melakukan analisis data berskala interval. Hal ini untuk memenuhi persyaratan bahwa dalam melakukan analisis data dengan analisis jalur atau path analysis, data minimal harus berskala interval. Untuk keperluan transformasi data dari skala ordinal ke skala interval digunakan Methode of Successive Interval (MSI).

Dalam melakukan analisis jalur atau path analysis, ada suatu persyaratan yang harus dipenuhi, yaitu adanya hubungan atau korelasi antar variabel pada seluruh variabl bebas yang terlibat. Dalam penelitian ini berarti harus ada hubungan atau korelasi antara variabel $\mathrm{X} 1, \mathrm{X} 2$, dan X3. Hubungan antar variabel ini 
ISSN 1412-2936

EISSN 2549-7308

ditunjukkan oleh nilai koefisien korelasinya. Perhitungan analisis korelasi antar variabel tersebut dianalisis dengan menggunakan Korelasi Pearson Product Moment, yaitu untuk mengetahui seberapa kuat hubungan antar variabel bebas dalam penelitian ini. Untuk keperluan ini digunakan perangkat berupa software SPSS versi 25. Hasil yang diperoleh adalah sebagai berikut :

Tabel Hasil Korelasi antar Variabel

\section{Correlations}

\begin{tabular}{|c|c|c|c|c|}
\hline \multirow{3}{*}{$\overline{X 1}$} & & \multirow{3}{*}{$\frac{\mathrm{X} 1}{1}$} & \multirow{3}{*}{$\frac{X 2}{, 219^{*}}$} & \multirow{3}{*}{$\frac{X 3}{, 221}$} \\
\hline & Pearson & & & \\
\hline & Correlation & & & \\
\hline & Sig. (2-tailed) & & ,028 &, 027 \\
\hline & $\mathrm{N}$ & 100 & 100 & 100 \\
\hline \multirow[t]{4}{*}{ X2 } & Pearson & ,219* & 1 & ,124 \\
\hline & Correlation & & & \\
\hline & Sig. (2-tailed) &, 028 & & ,219 \\
\hline & $\mathrm{N}$ & 100 & 100 & 100 \\
\hline \multirow[t]{4}{*}{ X3 } & Pearson &, $221^{*}$ & ,124 & 1 \\
\hline & Correlation & & & \\
\hline & Sig. (2-tailed) & ,027 & ,219 & \\
\hline & $\mathrm{N}$ & 100 & 100 & 100 \\
\hline
\end{tabular}

*. Correlation is significant at the 0.05 level (2-tailed).

Sumber : Hasil Pengolahan Data Primer dengan SPSS Versi 25

Pengaruh Variabel Bebas (X1, X2, dan X3) terhadap Variabel Intervening (Y)

Analisis jalur digunakan untuk mengetahui besarnya kontribusi pengaruh variabel bebas (X1, X2, dan X3) terhadap variabel intervening ( $Y$ ). Pengaruh yang dimaksud disini adalah pengaruh langsung dan pengaruh tidak langsung dari masing-masing variabel bebas tersebut. Besarnya pengaruh langsung diperoleh dengan cara mengkuadratkan koefisien jalur yang dimaksud. Sedangkan besarnya pengaruh tidak langsung diperoleh dengan cara mengalikan koefisien jalur yang terlibat dengan koefisien korelasinya. Analisis korelasi dan regeresi merupakan dasar dari perhitungan koefisien jalur. 
Tabel Pengaruh Parsial dan Simultan Variabel Merek (X1), Desain Produk (X2), Harga (X3) dan Keputusan Pembelian (Y)

\begin{tabular}{|c|c|c|c|c|c|c|}
\hline \multicolumn{7}{|c|}{ Coefficients $^{a}$} \\
\hline \multirow{2}{*}{\multicolumn{2}{|c|}{ Model }} & \multicolumn{2}{|c|}{$\begin{array}{l}\text { Unstandardized } \\
\text { Coefficients }\end{array}$} & \multirow{2}{*}{$\begin{array}{c}\text { Standardized } \\
\text { Coefficients } \\
\text { Beta } \\
\end{array}$} & \multirow[b]{2}{*}{$\mathrm{t}$} & \multirow[b]{2}{*}{ Sig. } \\
\hline & & $B$ & Std. Error & & & \\
\hline \multirow[t]{4}{*}{1} & (Constant) & 1,175 & 1,133 & & 1,037 & ,302 \\
\hline & $\mathrm{X} 1$ & ,306 & ,041 & ,609 & 7,536 & ,000 \\
\hline & $\mathrm{X} 2$ & , 128 & ,082 & , 125 & 1,570 & ,120 \\
\hline & X3 &, 010 & ,030 & ,025 & ,321 & ,749 \\
\hline
\end{tabular}

a. Dependent Variable: $Y$

\begin{tabular}{lc|c|c|c} 
& & \multicolumn{2}{c}{ Model Summary } \\
Model & $\mathrm{R}$ & $\mathrm{R}$ Square & $\begin{array}{c}\text { Adjusted R } \\
\text { Square }\end{array}$ & $\begin{array}{c}\text { Std. Error of } \\
\text { the Estimate }\end{array}$ \\
\hline 1 &, $654^{\mathrm{a}}$ &, 428 &, 410 & 1,31503 \\
\hline
\end{tabular}

a. Predictors: (Constant), X3, X2, X1

Sumber : Hasil Pengolahan Data Primer Menggunakan SPSS Versi 25

Setelah mengetahui besarnya koefesien korelasi antar variabel bebas dan besarnya koefisien jalur dari masingmasing variabel bebas tersebut terdapat variabel intervening (yang akan dijadikan sebagai perhitungan pengaruh langsung dan tidak langsung variabel bebas terhadap variabel intervening), maka selanjutnya adalah mengetahui pengaruh secara bersamaan atau pengaruh simultan dari seluruh variabel bebas tersebut (X1, X2, dan X3) terhadap variabel interveningnya $(Y)$.

\section{Pengaruh Variabel Intervening $Y$ terhadap Variabel Terikat Z}

Analisis jalur juga digunakan untuk mengetahui besarnya kontribusi pengaruh hubungan kausal antara variabel intervening $(\mathrm{Y})$ dengan variabel terikat (Z). Dalam hal penelitian ini variabel intervening atau $\mathrm{Y}$ adalah keputusan pembelian, sedangkan variabel terikat atau $\mathbf{Z}$ adalah kepuasan pelanggan. Dimana tingkat kepuasan pelanggan diperoleh dari selisih tingkat kepentingan produk dikurangi dengan tingkat kinerja produk. Untuk mengetahui besarnya pengaruh variabel $Y$ terhadap variabel $Z$, pertama kali menentukan besarnya nilai koefisien jalur (Standardized Coefficient (Beta)) dan signifikansi pengaruh variabel $Y$ terhadap Z (sig). Selanjutnya untuk besarnya pengaruh variabel $\mathrm{Y}$ terhadap $\mathrm{Z}$ ditentukan oleh nilai koefisien determinasinya atau $R$ Square. Berikut ini adalah tabel yang menunjukkan besarnya koefisien jalur, tingkat signifikansi, dan besarnya pengaruh 
ISSN 1412-2936

EISSN 2549-7308

variabel $Y$ tehadap $Z$ yang diperoleh dari hasil analisis jalur melalui fasilitas analyze regression linier yang ada pada software SPSS versi 25 :

Tabel Koefisien Jalur, Signifikansi, dan Besarnya Pengaruh Keputusan Pembelian (Y) dan Kepuasan Pelanggan (Z)

\begin{tabular}{|c|c|c|c|c|c|c|}
\hline \multicolumn{7}{|c|}{ Coefficients $^{a}$} \\
\hline \multirow{2}{*}{\multicolumn{2}{|c|}{ Model }} & \multicolumn{2}{|c|}{$\begin{array}{c}\text { Unstandardized } \\
\text { Coefficients }\end{array}$} & \multirow{2}{*}{$\begin{array}{c}\text { Standardized } \\
\text { Coefficients } \\
\text { Beta } \\
\end{array}$} & \multirow[b]{2}{*}{$\mathrm{t}$} & \multirow[b]{2}{*}{ Sig. } \\
\hline & & $\mathrm{B}$ & Std. Error & & & \\
\hline \multirow[t]{2}{*}{1} & (Constant) & 5,344 & ,787 & & 6,790 &, 000 \\
\hline & Y & ,440 & ,081 & ,483 & 5,459 &, 000 \\
\hline
\end{tabular}

a. Dependent Variable: $Z$

\section{Model Summary}

\begin{tabular}{lc|c|c|c} 
Model & $\mathrm{R}$ & $\mathrm{R}$ Square & $\begin{array}{c}\text { Adjusted R } \\
\text { Square }\end{array}$ & $\begin{array}{c}\text { Std. Error of } \\
\text { the Estimate }\end{array}$ \\
\hline 1 &, $483^{\mathrm{a}}$ &, 233 &, 225 & 1,37136 \\
\hline
\end{tabular}

a. Predictors: (Constant), Y

Sumber : Hasil Pengolahan Data Primer Menggunakan SPSS Versi 25

Dengan demikian dapat diketahui hasil perhitungan analisis jalur setiap variabel sebagaimana digambarkan pada diagram berikut :

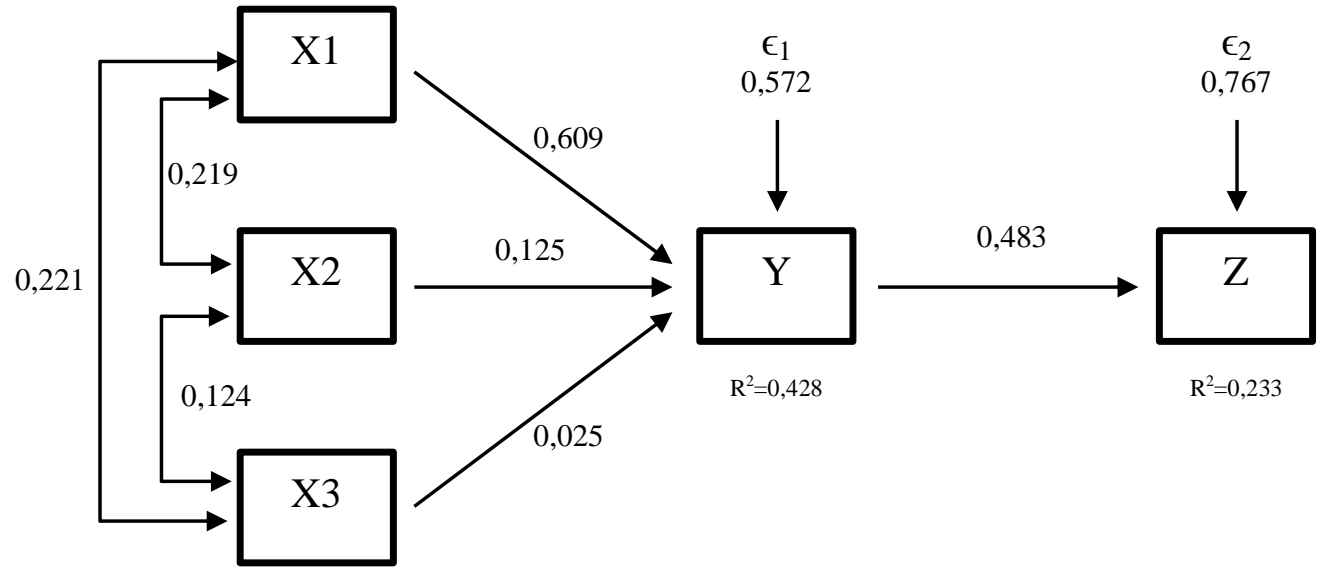

Gambar Hasil Analisis Jalur

Gambar hasil analisis jalur diatas menunjukkan hasil perhitungan koefisien jalur, dimana variabel X1 mempunyai kefisien jalur 0,609; variabel X2

mempunyai koefisien jalur 0,125 ;

variabel X3 mempunyai koefisien jalur 
0,025; dan variabel Y mempunyai

koefisien jalur 0,483. Sehingga

$Y=0,609 X_{1}+0,125 X_{2}+0,025 X_{3}+\epsilon_{1}$

$Z=\mathbf{0}, 483 Y+\epsilon_{2}$

Pengaruh Langsung dan Tidak Langsung dari Variabel Bebas (Merek (X1), Desain Produk (X2), dan Harga (X3)) Terhadap Variabel Keputusan Pembelian

Perhitungan pengaruh langsung (direct effect) dan pengaruh tidak langsung persamaan jalur yang diperoleh adalah :

(indirect effect) dari variabel merek (X1), Desain Produk (X2) dan Harga (X3) terhadap variabel keputusan pembelian (Y) secara keseluruhan adalah sebagaimana dilihat pada tabel pengaruh langsung dan tidak langsung berikut :

Tabel Pengaruh Langsung, Pengaruh Tidak Langsung dan Pengaruh Total

\begin{tabular}{l|c|c|c|c|c}
\hline \multirow{2}{*}{ Variabel } & \multicolumn{5}{|c}{ Keputusan Pembelian (Y) } \\
\cline { 2 - 5 } & $\begin{array}{l}\text { Pengaruh } \\
\text { Langsung } \\
(\%)\end{array}$ & \multicolumn{2}{|c|}{ Prngaruh Tidak Langsung (\%) } & \multirow{2}{*}{$\begin{array}{c}\text { Pengaruh } \\
\text { Total (\%) }\end{array}$} \\
\cline { 5 - 6 } & 37,09 & - & 1,67 & 0,34 & 39,1 \\
\hline Merek (X1) & 1,56 & 1,67 & - & 0,04 & 3,27 \\
\hline Desain Produk (X2) & 0,06 & 0,34 & 0,04 & - & 0,44 \\
\hline Harga (X3) & 39,52 & 2,01 & 1,71 & 0,38 & $\mathbf{4 2 , 8 1}$ \\
\hline Pengaruh Total & 39 &
\end{tabular}

Sumber : Diolah dari Data Primer

Pengaruh Variabel Merek (X1) paling besar dibandingkan dengan terhadap variabel Keputusan Pembelian (Y) Kelom Sheny

Pengaruh total variabel merek (X1) terhadap variabel keputusan pembelian (Y) sebesar 0,391 atau 39,1\%. Apabila dikonfirmasi dengan tabel sebelumnya, maka pengaruh ini termasuk dalam kategori ada pengaruhnya. Walaupun pengaruhnya sebesar $39,1 \%$ variabel ini tetap memberikan kontribusi terhadap keputusan pembelian. Pengaruh langsung variabel merek (X1) terhadap variabel keputusan pembelian (Y) pengaruh langsung variabel bebas lainnya. Ini menunjukkan bahwa variabel merek (X1) merupakan faktor yang paling berpengaruh peranannya terhadap keputusan pembelian (Y). Di dalam penelitian ini variabel merek merupakan pertimbangan utama dalam keputusan pembelian, karena konsumen / pelanggan sudah mengetahui merek yang berkualitas tersebut. Oleh sebab itu, merupakan prioritas utama yang harus dipertahankan agar keputusan pembelian dapat stabil.

sebesar $37,09 \%$ merupakan pengaruh 
Pengaruh Variabel Desain Produk (X2) terhadap Variabel Keputusan Pembelian (Y) Kelom Sheny

Pengaruh total variabel desain produk (X2) terhadap variabel keputusan pembelian (Y) sebesar 0,0327 atau $3,27 \%$. Apabila dikonfirmasi dengan tabel sebelumnya, maka pengaruh ini termasuk dalam kategori ada pengaruhnya. Walaupun pengaruhnya sebesar $3,27 \%$ variabel ini tetap memberikan kontribusi terhadap keputusan pembelian. Pengaruh langsung variabel desain produk (X2) terhadap variabel keputusan pembelian (Y) sebesar 1,56\% merupakan pengaruh yang kecil dibandingkan dengan pengaruh langsung variabel bebas lainnya. Hal ini disebabkan karena desain produk tidak memiliki khas tersendiri (desain produk yang ditawarkan sama dengan desain yang telah beredar dipasaran). Dengan kata lain, walaupun merek telah banyak dikenal sedangkan desain produk tidak berkembang dan tidak memiliki khasnya tersendiri, maka konsumen tidak akan menentukan keputusan pembelian produk tersebut.

\section{Pengaruh Variabel Harga (X3) terhadap Variabel Keputusan Pembelian (Y) Kelom Sheny}

Pengaruh total variabel harga (X3) terhadap variabel keputusan pembelian (Y) sebesar 0,0044 atau $0,44 \%$.
Pengaruh langsung variabel harga (X3) terhadap variabel keputusan pembelian (Y) sebesar 0,06 merupakan pengaruh yang paling kecil dibandingkan dengan pengaruh variabel bebas lainnya. Hal ini menunjukkan bahwa harga yang ditawarkan pada setiap produk ini relatif tinggi karena disebabkan adanya penurunan daya beli dari masyarakat khususnya di kota Tasikmalaya. Harga merupakan faktor penting dalam menentukan keputusan pembelian. Oleh sebab itu variabel harga ini perlu ditingkatkan (dimensi-dimensi harga lebih ditingkatkan lagi) agar keputusan pembelian lebih meningkat (setelah prioritas peningkatan terhadap merek dan desain produk).

Pengaruh Variabel Merek (X1), Desain Produk (X2), dan Harga (X3) terhadap Variabel Keputusan Pembelian (Y)

Berdasarkan hasil pengolahan data pada tabel sebelumnya, terlihat bahwa besarnya koefisien $\mathrm{R}^{2}$ ( $R$ square) bernilai 0,428 atau $42,8 \%$. Nilai ini adalah hasil penjumlahan pengaruh variabel merek (X1) sebesar $39,1 \%$, variabel desain produk (X2) sebesar 3,27\%, dan variabel harga (X3) sebesar 0,44\%. Sedangkan sisanya sebesar $57,2 \%$ adalah kontribusi dari variabel lain yang tidak diteliti dalam penelitian ini. Dengan demikian hanya ada satu variabel bebas yang berpengaruh signifikan secara parsial dan simultan, yaitu variabel merek (X1). 
Pengaruh Variabel Keputusan

Pembelian (Y) terhadap Kepuasan Pelanggan (Z)

Berdasarkan hasil pengolahan data pada tabel sebelumnya, terlihat bahwa besarnya koefisien jalur adalah 0,483, sedangkan koefisien determinasi $\mathrm{R}^{2}$ ( $R$ square) bernilai 0,233 atau $23.3 \%$. Sedangkan sisanya sebesar 0,767 atau $76,7 \%$ adalah kontribusi dari variabel lain yang tidak diteliti dalam penelitian ini. Variabel Keputusan Pembelian (Y) memiliki pengaruh yang signifikan terhadap variabel kepuasan pelanggan (Z) kelom sheny. Pengaruh tersebut apabila dikonfirmasi dengan tabel sebelumnya, maka termasuk ke dalam pengaruh yang tinggi.

\section{PENUTUP}

Kesimpulan

Pengaruh merek ini merupakan pengaruh yang paling dominan terhadap keputusan pembelian, karena pengaruh langsungnya dibandingkan dengan variabel bebas lainnya. Dengan demikian variabel merek merupakan prioritas utama dalam meningkatkan keputusan pembelian. Pengaruh desain produk merupakan pengaruh terbesar kedua setelah pengaruh merek. Ini menunjukkan bahwa desain produk masih merupakan pengaruh yang dominan (setelah variabel merek) terhadap keputusan pembelian. Dengan demikian variabel desain produk merupakan prioritas yang harus ditingkatkan (setelah prioritas merek) untuk mengingkatkan keputusan pembelian. Pengaruh variabel harga memiliki pengaruh terkecil, hal ini antara lain disebabkan adanya pengaruh variabel lain selain merek dan desain produk terhadap keputusan pembelian. Meskipun pengaruhnya tidak sebesar variabel merek dan desain produk, variabel harga masih dapat menjadi prioritas yang harus ditingkatkan (setelah prioritas terhadap merek, dan desain produk) untuk meningkatkan keputusan pembelian. Variabel Keputusan Pembelian memiliki pengaruh yang signifikan terhadap variabel kepuasan pelanggan kelom sheny.

\section{Saran}

Dari hasil penelitian ini bisa dijadikan bahan pertimbangan bagi produsen untuk perbaikan dimensi-dimensi produk di masa mendatang, terutama dimensi harga yang memiliki nilai terendah. Perlu ditekankan bahwa, harus adanya kebijakan penurunan harga jual barang, maka harus diperhatikan dengan seksama, jangan sampai penurunan harga ini menyebabkan penurunan kualitas. Diperlukan perhitungan yang cermat agar keseimbangan antara peningkatan dimensi tempat dan biaya yang harus dikeluarkan oleh perusahaan, 
sehingga tidak harus menaikkan harga jual produk. Perusahaan dapat menerapkan jaminan kepada konsumen (misal dengan cara memberikan garansi produk atau servis gratis selama kurun waktu tertentu). Tidak kalah pentingnya perusahaan harus memperhatikan faktor kecepatan dalam melayani delivery order tersebut. Dengan demikian pelanggan akan tetap merasa puas dan tidak akan berpaling pada produk yang lain, bahkan pada gilirannya bisa melakukan pembelian ulang atau repeat order (menjadi pelanggan yang loyal) dan pelanggan tersebut dapat pula menjadi pemasar yang baik melalui word of mouth pada pelanggan atau calon pelanggan potensial lainnya.

\section{DAFTAR PUSTAKA}

(1) Kotler, Philip, 2009, Manajemen Pemasaran, Edisi Millenium, Penerbit PT. Prenhallindo, Jakarta.

(2) Lim.et.al. 2008. Sustainble Marketing Enterprise In Asia. Prentice Hall.

(3) Kotler, P. \& Armstrong, G. 2009, marketing an introduction, Ninth Edition. New Jersey: Prentice Hall.
(4) Gobe, Marc. 2009, Emotional Branding, Jakarta, penerbit : Erlangga.

(5) Fandy Tjiptono, 2008. Prinsip dan Dinamika Pemasaran. $\mathrm{J} \& \mathrm{~J}$ Learning, Yogyakarta.

(6) Fandy Tjiptono, 2008, Strategi Pemasaran, Penerbit Andi, Yogyakarta.

(7) Rachim, T. \& Setiawan, I. (2014), The Effects of Product Attributes and Pricing Policy to Netbook Purchase Decision: (Case Study of Universitas Widyatama Students), International Journal of Science and Research (IJSR)Vol. 3 Issue 4 April 2014.

(8) Evelina dkk., (2013), Harga, kualitas produk dan kualitas pelayanan pengaruhnya terhadap keputusan pembelian mobil Toyota Avanza, Jurnal EMBA1251Vol.1No.3 September 2013, Hal. 1251-1259.

(9) Alma, Buchari. 2008, Manajemen Pemasaran \& Pemasaran Jasa. Bandung: CV. Alfabeta.

(10) Mowen, John, C., dan Minor, M., 2009, Perilaku Konsumen Jilid 1, Edisi Kelima (terjemahan), Erlangga, Jakarta.

(11) Husain Umar, 2010, Riset Pemasaran dan Perilaku Konsumen, PT Gramedia Pustaka Utama, Jakarta.

(12) Indriantoro, N., Bambang S., 2009, Metodologi Penelitian Bisnis untuk Akuntansi dan Manajemen, Edisi Pertama, Yogyakarta, BPFE Yogyakarta 